\title{
Prevalence and molecular characterization of canine parvovirus
}

\author{
Parikshit Singh(D), Gurpreet Kaur(iD, Mudit Chandra (iD) and P. N. Dwivedi(i) \\ Department of Veterinary Microbiology, College of Veterinary Science, Guru Angad Dev Veterinary and Animal Sciences \\ University, Ludhiana, Punjab, India. \\ Corresponding author: Gurpreet Kaur, e-mail: gurpreet7502@rediffmail.com \\ Co-authors: PS: ipariksingh@gmail.com, MC: drmuditchandra@rediffmail.com, PND: dwivedi_micro@yahoo.co.in \\ Received: 18-08-2020, Accepted: 21-01-2021, Published online: 09-03-2021
}

doi: www.doi.org/10.14202/vetworld.2021.603-606 How to cite this article: Singh P, Kaur G, Chandra M, Dwivedi PN (2021) Prevalence and molecular characterization of canine parvovirus, Veterinary World, 14(3): 603-606.

\begin{abstract}
Background and Aim: Canine parvovirus (CPV) belonging to family Parvoviridae causes hemorrhagic gastroenteritis in dogs and heavy mortality in young dogs. The virus has three structural (VP1, VP2 and VP3) and two non-structural proteins (NS1 and NS2), VP2 being highly immunogenic. This study aims to study molecular epidemiology of CPV by sequence analysis of VP2 gene to determine the prevailing antigenic type(s) in the northern regions of India.
\end{abstract}

Materials and Methods: A total of 118 rectal swabs collected from dogs exhibiting clinical signs of CPV infection were processed for the isolation of DNA and subjected to polymerase chain reaction (PCR) and nested PCR (NPCR). A total of 13 NPCR products selected randomly were subjected to sequence analysis of VP2 gene.

Results: The percent positivity of CPV was found $28 \%$ and $70 \%$ by PCR and NPCR, respectively. Dogs with vaccination history against CPV too were found positive with a percent positivity of $24.10 \%$. Gene sequencing and phylogenetic analysis of VP2 gene from these isolates revealed that most samples formed a clade with CPV-2a isolates.

Conclusion: Sequence analysis and phylogenetic analysis of VP2 gene in the studied regions of northern India revealed that CPV-2a was the most prevalent antigenic type.

Keywords: canine parvovirus, nested polymerase chain reaction, polymerase chain reaction, sequence analysis, $V P 2$ gene.

\section{Introduction}

Canine parvovirus (CPV) is a highly contagious virus and a common cause of acute, infectious gastrointestinal disease affecting young/unvaccinated dogs. It is among the smallest known viruses ( approx. $25 \mathrm{~nm}$ in diameter) belonging to the genus Protoparvovirus of the family Parvoviridae [1]. CPV is a non-enveloped icosahedral virion with a linear, non-segmented, negative sense, single-stranded DNA genome of 5323 bases which encodes for three structural proteins (VP1, VP2, and VP3) and two non-structural (NS) proteins (NS1 and NS2). VP2 is the major structural protein of capsid and its antigenic determinant. Earliest known CPV-positive sera were reported in Greece in 1974. CPV was first identified during mid-1978 as an emerging pathogen [2,3] and was referred to as CPV-2 to distinguish it from CPV-1 [4]. In India, CPV-2 was initially reported from Madras by Balu and Thangaraj [5] and was first isolated by Ramadass and Khader [6].

Some amino acid substitutions in VP2 gene sequence can lead to mutations in CPV which is mainly responsible for resulting in different antigenic

Copyright: Singh et al. Open Access. This article is distributed under the terms of the Creative Commons Attribution 4.0 International License (http://creativecommons.org/licenses/by/4.0/), which permits unrestricted use, distribution, and reproduction in any medium, provided you give appropriate credit to the original author(s) and the source, provide a link to the Creative Commons license, and indicate if changes were made. The Creative Commons Public Domain Dedication waiver (http://creativecommons.org/ publicdomain/zero/1.0/) applies to the data made available in this article, unless otherwise stated. variants of the virus [7,8]. At present, there are four known antigenic types of CPV circulating throughout the world, namely, CPV-2, CPV-2a, CPV-2b, and CPV-2c. As the knowledge regarding current antigenic types of CPV in North India is still limited, more seroprevalence data and sequencing VP2 gene for the detection of mutations would be of great help in the identification of the possible new emerging CPV strains.

Thus, the present study was designed to detect and identify the prevailing antigenic type(s) of CPV in different regions of North India.

\section{Materials and Methods}

Ethical approval

The Institutional Animal Ethics Committee permission was obtained through Memo No: GADVASU/2018/IAEC/47/19.

\section{Study period and location}

The samples were collected from July 2019 to February 2020. The study was conducted at the Department of Veterinary Microbiology, COVS, Guru Angad Dev Veterinary and Animal Sciences University, Ludhiana.

\section{Collection of samples}

A total of 118 rectal swabs were collected in $4 \mathrm{~mL}$ phosphate buffer saline $(\mathrm{pH}=7.2)$ from dogs exhibiting gastroenteritis/hemorrhagic enteritis with pyrexia, vomiting, dehydration, etc. Samples were collected from Friendicoes, New Delhi $(n=35)$; Gurugram, Haryana $(\mathrm{n}=16)$; Chandigarh $(\mathrm{n}=6)$; 
Jammu ( $\mathrm{n}=6)$; and the Small Animal Referral Veterinary Clinics, Guru Angad Dev Veterinary and Animal Sciences University (GADVASU), Ludhiana, Punjab $(n=55)$. A rectal swab sample from a healthy dog too was collected and was used as negative control. A vaccine Nobivac DHPPi (Merck, Germany) was procured from a local drug store, Ludhiana, Punjab. The DNA was extracted from all the samples and the vaccine using the phenol-chloroform extraction method as described by Russell and Sambrook [9].

\section{Polymerase chain reaction (PCR) for the detection of CPV}

The primers used in the PCR for the detection of CPV in rectal swabs were as per Mizak and Rzezutka [10]. The PCR reaction mixture was prepared by adding $15 \mu \mathrm{L}$ of the template DNA, $5.0 \mu \mathrm{L}$ of $10 \times$ PCR buffer (with $15 \mathrm{mM} \mathrm{MgCl}$ ), $1.0 \mu \mathrm{L}$ of forward and reverse primer $(20 \mathrm{pm} / \mu \mathrm{L})$ each, $1.0 \mu \mathrm{L}$ of dNTPs mix (10 mM each) (Takara Bio, USA), $0.2 \mu \mathrm{L}$ Taq DNA polymerase (5 units $/ \mu \mathrm{L}$ ) (Qiagen, Germany), and the final reaction mixture volume was made up to $50 \mu \mathrm{L}$ using nuclease-free water.

\section{Nested PCR (NPCR) for the detection of CPV}

The primers for NPCR for the detection of CPV were as per Mizak and Rzezutka [10]. The NPCR reaction mixture was prepared by adding $5 \mu \mathrm{L}$ of the PCR product (from above), $2.5 \mu \mathrm{L}$ of $10 \times$ PCR buffer (with $15 \mathrm{mM} \mathrm{MgCl}$ ), $1.0 \mu \mathrm{L}$ each of forward and reverse primer $(20 \mathrm{pm} / \mu \mathrm{L}), 1.0 \mu \mathrm{L}$ of dNTPs (10 mM each) (Takara Bio), $0.2 \mu \mathrm{L}$ Taq DNA polymerase ( 5 units $/ \mu \mathrm{L})$ Qiagen), and the final volume was made up to $25 \mu \mathrm{L}$ by adding nuclease-free water.

Both PCR and NPCR were set at thermocycling parameters with 35 cycles of denaturation at $94^{\circ} \mathrm{C}$ for $60 \mathrm{~s}$, annealing at $55^{\circ} \mathrm{C}$ for $60 \mathrm{~s}$, elongation at $72^{\circ} \mathrm{C}$ for $150 \mathrm{~s}$, and a final elongation at $72^{\circ} \mathrm{C}$ for $10 \mathrm{~min}$. Both PCR and NPCR products ( $10 \mu \mathrm{L}$ each) were subjected to agarose gel electrophoresis using $1 \%$ agarose at the rate of 5 volts $/ \mathrm{cm}$ with Gene Ruler ladder plus 100 bp (New England Biolabs, USA). The products on gel were visualized and documented using gel documentation system (Syngene, USA).

\section{VP2 gene sequencing}

A total of 13 NPCR products (Table-1) were purified using UltraClean PCR Clean-Up Kit (Mo Bio Labs., Inc., USA) and were submitted for sequencing (Eurofins Genomics, India Pvt. Ltd.). These sequences were analyzed and compared with the CPV sequences available from the GenBank using NCBI BLAST (http://blast.ncbi.nlm.nih.gov/blast.cgi) and Clustal Omega (www.ebi.ac.uk/tools/msa/clustalo/).

\section{Results}

\section{PCR and NPCR}

Out of 118 CPV DNA samples subjected to both PCR and NPCR, a total of 33 samples were found to be positive for PCR with an incidence of $28 \%$ with a product yield of $1198 \mathrm{bp}$ (Figure-1) and 83 samples were found to be positive for NPCR with an incidence of $70 \%$ with a product yield of 548 bp (Figure-2). Age-wise status of NPCR-positive samples indicated that $73.49 \%$ of samples belonged to dogs below 3.5

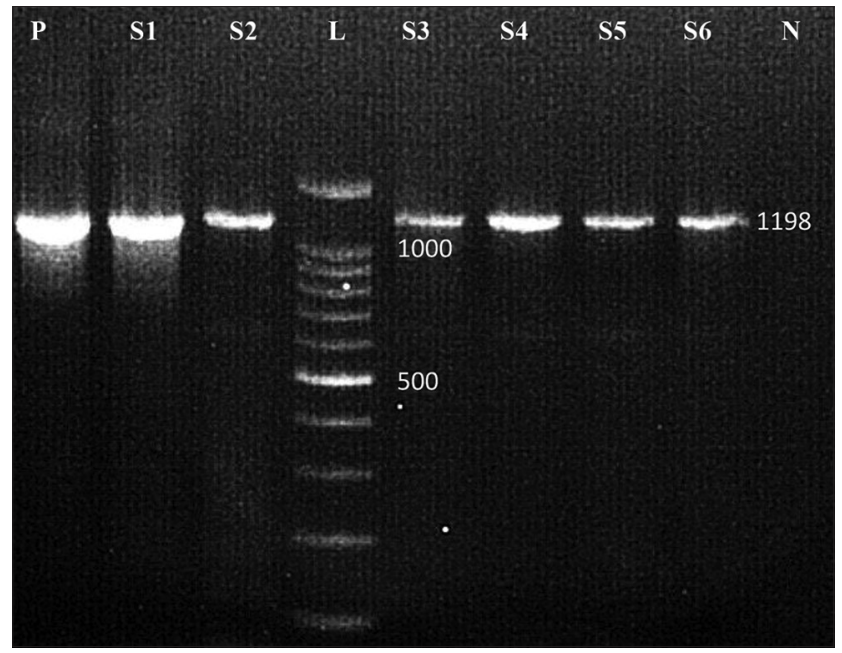

Figure-1: Polymerase chain reaction product visualization gel run. Lane $L=100$ bp plus ladder, $P=$ Positive control, $\mathrm{N}=$ Negative control, S1-S6=CPV samples.

Table-1: History of CPV samples randomly selected for sequencing from various regions of North India.

\begin{tabular}{|c|c|c|c|c|c|c|}
\hline Sample No. & Age (Months) & Sex & Breed & PCR & Nested PCR & Vaccination/booster status \\
\hline D1 & 1.5 & Female & Mongrel & + & + & - \\
\hline D2 & 1.5 & Male & Mongrel & - & + & - \\
\hline P1 & 3 & Female & Mongrel & + & + & - \\
\hline P7 & 6 & Male & Mongrel & + & + & - \\
\hline P9 & 1 & Female & Pomeranian & - & + & - \\
\hline P10 & 1 & Female & American Bully & - & + & - \\
\hline P19 & 6 & Female & Pomeranian & - & + & - \\
\hline P47 & 7 & Male & Mongrel & + & + & - \\
\hline P48 & 3 & Male & $\begin{array}{l}\text { Labrador } \\
\text { Retriever }\end{array}$ & + & + & $\begin{array}{l}\text { Vaccinated and booster also } \\
\text { given }\end{array}$ \\
\hline P51 & 4 & Female & Dachshund & + & + & - \\
\hline C2 & 3.5 & Female & Dobermann & + & + & Vaccinated \\
\hline C6 & 4 & Female & Cocker Spaniel & + & + & $\begin{array}{l}\text { Vaccinated and booster also } \\
\text { given }\end{array}$ \\
\hline J1 & 4 & Female & Mongrel & + & + & - \\
\hline
\end{tabular}

$\mathrm{CPV}=$ Canine parvovirus, $\mathrm{PCR}=$ Polymerase chain reaction 
months of age. Sex-wise status of NPCR positive samples indicated that $60.24 \%$ samples belonged to males, while $39.76 \%$ samples belonged to females. Vaccination status of NPCR-positive samples indicated that $75.90 \%$ samples belonged to unvaccinated dogs, while $24.10 \%$ samples belonged to vaccinated dogs.

\section{Sequence analysis}

On the basis of NCBI BLAST analysis, it was found that the sequences had $99-100 \%$ homology with the existing CPV sequences. Phylogenetic analysis of subjected samples revealed that most of them formed a similar clade with CPV 2a isolates (Figure-3) and a separate clade with CPV-2b and CPV-2c sequences from GenBank (Figures-4 and 5).

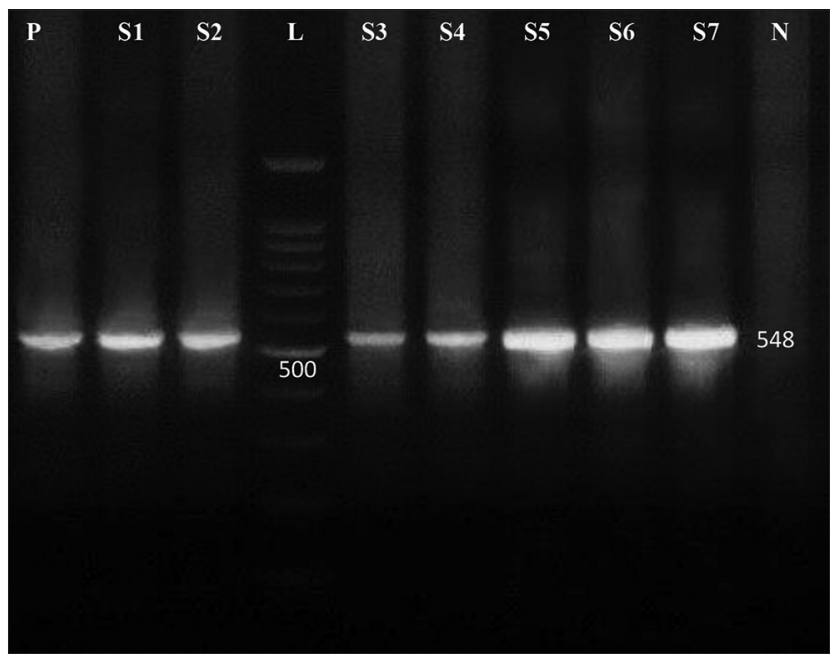

Figure-2: Nested polymerase chain reaction product visualization gel run. Lane $\mathrm{L}=100$ bp plus ladder, $\mathrm{P}=$ Positive control, $\mathrm{N}=$ Negative control, $\mathrm{S} 1-\mathrm{S} 7=\mathrm{CPV}$ samples.

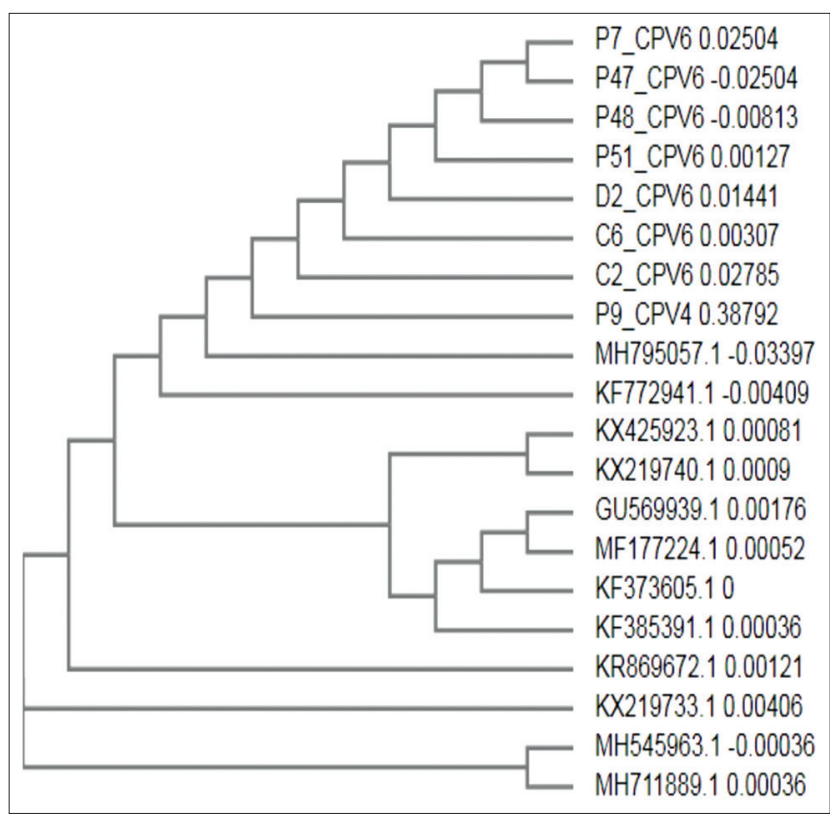

Figure-3: Phylogenetic analysis of canine parvovirus (CPV) samples with CPV $2 a$ sequences from GenBank. Lane $\mathrm{L}=100$ bp plus ladder, $\mathrm{P}=$ Positive control, $\mathrm{N}=$ Negative control, S1-S7=CPV samples.

\section{Discussion}

Since the emergence of CPV in 1978, the virus had been known to continually evolve into many antigenic variants that can be found all over the world. This great antigenic variability of CPV due to its high mutation rates has raised a concern for the potential disease outbreak leading to negative impact on the health of primarily domestic dogs. Studying the ongoing status of geographical prevalence of particular antigenic type(s) is of key importance to keep a check on the mutating antigenic types to ensure the good health of dogs in future. In the present study, the prevalence of CPV antigenic types was studied in different regions of North India. The results of the present study aligned with the findings of many earlier researchers from India who did the sequence analysis of $V P 2$ gene of CPV to understand its prevailing antigenic types. Molecular characterization of field isolates of CPV and their sequence analysis of $V P 2$ gene revealed that CPV 2a was found to be the most prevailing antigenic type in the studied regions of North India, while NPCR was found to be a more sensitive molecular

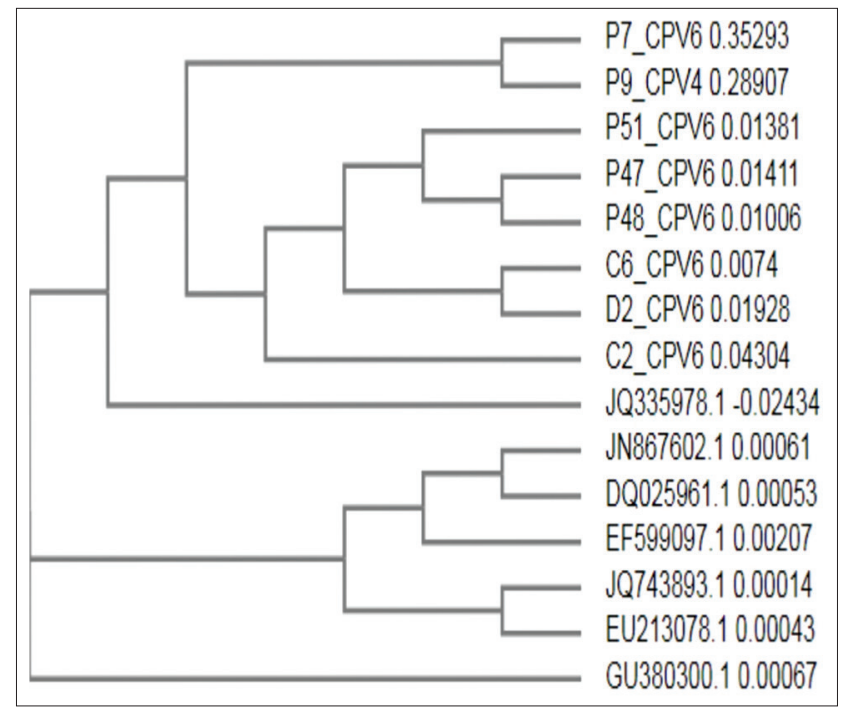

Figure-4: Phylogenetic analysis of canine parvovirus (CPV) samples with CPV 2b sequences from GenBank.

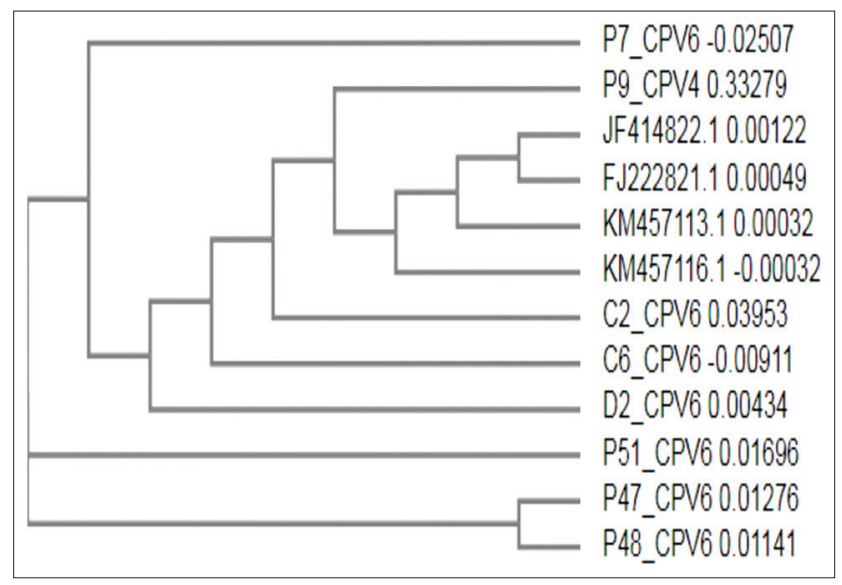

Figure-5: Phylogenetic analysis of canine parvovirus (CPV) samples with CPV 2c sequences from GenBank. 
technique than conventional PCR for the detection of CPV. The present study also reinforced the established fact that among pedigreed dogs, breeds such as Labrador retriever, German shepherd, and Pomeranian were most affected, while dogs below 3.5 months of age were at greater risk and males were having more percent positivity. With the sequence analysis of $V P 2$ gene, the prevalence of CPV 2a has been commonly observed in many earlier studies [8,11-18]. Similarly, a few studies have also indicated the presence of both CPV 2a and CPV 2b $[8,11]$ in the samples from dogs. Similarly, a new variant of CPV $2 a$ and CPV-2b types circulating in the dog population of Brazil has been reported[19], and a new variant of CPV 2a was detected from Colombia [20].

\section{Conclusion}

Sequence analysis of the VP2 gene of CPV field isolates collected from the regions of Punjab, New Delhi, Haryana, Chandigarh, and Jammu revealed that CPV 2a was the prevalent antigenic type circulating in these regions. Further, continued studies are needed to keep record of new mutations of CPV antigenic types and their prevalence in different geographical regions for better understanding and preparation of new vaccine strains.

\section{Authors' Contributions}

GK designed, planned, and supervised the study. PS performed all the experiments and collected the data. PS, GK, MC, and PND analyzed the results. PS and GK wrote the manuscript. MC and PND edited and finalized the manuscript. All authors read and approved the final manuscript.

\section{Acknowledgments}

The authors are thankful to Department of Biotechnology, Government of India for funding the project BT/ADV/Canine Health/TANUVAS/2017-18. The authors are also thankful to the Director of Research, GADVASU, Ludhiana, India, for all the help to carry out this work.

\section{Competing Interests} interests.

The authors declare that they have no competing

\section{Publisher's Note}

Veterinary World remains neutral with regard to jurisdictional claims in published institutional affiliation.

\section{References}

1. Cotmore, S.F. and Tattersall, P. (1990) In: Tijssen, P., editors. Handbook of Parvovirus. $1^{\text {st }}$ ed. CRC Press, USA, p123-140.

2. Appel, M.J.G. (1978) Status report: Canine viral enteritis. J.
Am. Vet. Med. Assoc., 173: 1516-1518.

3. Appel, M.J., Scott, F.W. and Carmichael, L.E. (1979) Isolation and immunisation studies of a canine parvo-like virus from dogs with haemorrhagic enteritis. Vet. Rec., 105(8): 156-159.

4. Parrish, C.R. and Carmichael, L.E. (1983) Antigenic structure and variation of canine parvovirus type-2, feline panleukopenia virus, and mink enteritis virus. Virology, 129(2): 401-414.

5. Balu, P.A. and Thangaraj, T.M. (1981) Canine viral gastroenteritis-a clinical report. Indian J. Vet. Med., 1: 73-77.

6. Ramadass, P. and Khader, T.G. (1982) Diagnosis of canine parvovirus infection by agar gel precipitation test and fluorescent antibody technique. Cherion, 11: 323-326.

7. Phromnoi, S., Sirinarumitr, K. and Sirinarumitr, T. (2010) Sequence analysis of $V P 2$ gene of canine parvovirus isolates in Thailand. Virus Genes, 41(1): 23-29.

8. Kaur, G., Chandra, M. and Dwivedi, P.N. (2016) Phylogenetic analysis of $V P 2$ gene of canine parvovirus and comparison with Indian and world isolates. Acta Virol., 60(1): 106-110.

9. Russell, D.W. and Sambrook, J. (2001) Molecular Cloning: A Laboratory Manual. Vol. 1. Cold Spring Harbor Laboratory, New York. p112.

10. Mizak, B.E.A. and Rzezutka, A.R.T. (1999) Application of nested PCR for the detection of canine parvovirus in faeces. Bull. Vet. Inst. Pulawy, 43(1): 19-24.

11. Kulkarni, M.B., Deshpande, A.R., Gaikwad, S.S., Majee, S.B., Suryawanshi, P.R. and Awandkar, S.P. (2019) Molecular epidemiology of Canine parvovirus shows CPV-2a genotype circulating in dogs from western India. Infect. Genet. Evol, 75: 103987.

12. Chinchkar, S.R., Subramanian, B.M., Rao, N.H., Rangarajan, P.N., Thiagarajan, D. and Srinivasan, V.A. (2006) Analysis of VP2 gene sequences of canine parvovirus isolates in India. Arch. Virol., 151(9): 1881-1887.

13. Kaur, G., Chandra, M., Dwivedi, P.N. and Sharma, N.S. (2014) Antigenic typing of canine parvovirus using differential PCR. Virusdisease, 25(4): 481-487.

14. Srinivas, V.M.V., Mukhopadhyay, H.K., Thanislass, J., Antony, P.X. and Pillai, R.M. (2013) Molecular epidemiology of canine parvovirus in Southern India. Vet. World, 6(10): 744-749.

15. Mukhopadhyay, H.K., Matta, S.L., Amsaveni, S., Antony, P.X., Thanislass, J. and Pillai, R.M. (2014) Phylogenetic analysis of canine parvovirus partial VP2 gene in India. Virus Genes, 48(1): 89-95.

16. Sharma, K.K., Kalyani, I.H., Pandya, S.M. and Vala, J.A. (2018) Diagnosis and characterization of canine parvovirus-2 affecting canines of South Gujarat, India. Acta Vet. Brno, 87(3): 247-254.

17. Kushwaha, S.S., Kaur, G., Chandra, M. and Dwivedi, P.N. (2018) Identification of the prevailing antigenic types of Canine parvovirus in Northern and Central India. Int. $J$. Curr. Microbiol. App. Sci., 7(8): 3881-3889.

18. Das, H., Kaur, G., Chandra, M. and Dwivedi, P.N. (2019) Detection of CPV 2a antigen type of Canine parvovirus in the States of Punjab and Assam, India. Curr. J. Appl. Sci. Technol., 38(2): 1-7.

19. de Oliveira, P.S.B., Cargnelutti, J.F., Masuda, E.K., Weiblen, R. and Flores, E.F. (2019) New variants of canine parvovirus in dogs in southern Brazil. Arch. Virol., 164(5): 1361-1369.

20. Giraldo-Ramirez, S., Rendon-Marin, S. and Ruiz-Saenz, J. (2020) Phylogenetic, evolutionary and structural analysis of canine parvovirus (CPV-2) antigenic variants circulating in Colombia. Viruses, 12(5): 500. 